УДК 342.7

DOI https://doi.org/10.32849/2663-5313/2021.2.27

\title{
Віталій Ковтун,
}

канд. юрид. наук, дочент

дочент кафедри конституиійного права Украйни

Національного юридичного університету імені Ярослава Мудрого

\section{КОНСТИТУЦЙНО-ПРАВОВА ДОКТРИНА СОЦІАЛЬНИХ ПРАВ ТА СВОБОД}

Участь у перерозподілі бюджетних коштів, створення мереж сочіального захисту та регулювання економіки започаткувало засади державної політики. У середині ХІХ століття, після заворушень 1848 року, розгорілася суперечка, яка затягнулася на десятиліття, про найбільш ефективний спосіб боротьби з бідністю - використання державного втручання в економіку або спирання на політику laissez-faire. Успіхи та невдачі держав і ринків відігравали в минулому сторіччі важливу роль у розвитку ідей про їхню місію. Усвідомлення ідеї «золотої середини» мало на меті збалансованість ролі ринків, держави і громадянського суспільства. Історичний процес осягнення феномена сочіальної держави призводив до появи особливостей американської та європейської конституціоналізації.

Підкреслюється особлива роль судових юрисдикиій різних правопорядків у розумінні ідеї держави загального добробуту. Конституиійні суди не повинні уникати відповідальності щодо реалізащіі в суспільстві соціальної справедливості, $і$ вони можуть досягнути иього иляхом конститутивного тлумачення. Зокрема, наведені приклади із судової практики Конституиійного Суду України щодо так званих «соціальних справ». У статті вказано, що сочіальні права можуть забезпечуватися правовими нормами і санкціями та відповідати судовому рішенню згідно із системою конституиійних скарг шляхом їх інтерпретування як «класичних прав».

Зазначено, що свогодні світове співтовариство перебуває у найглибшій реиесії з часів Другоі Світової Війни. Пандемія коронавірусної хвороби (Соvіd-19) постає небаченим випробуванням, що загрожує побудованій соиіальній солідарності та розширенню захисту прав людини. Початкові реакиії держав передбачають безпрецедентну чільову фіскальну та монетарну політику, щоб забезпечити сочіальний захист, одночасно стимулюючи економічний пошук задля запобігання занурюванню в глобальну депресію.

Доведено, що практика захисту прав людини у «молодих пострадянських державах» все більше рухається у напрямі нормативного та інституційного гарантування, тобто інструменту запобігання демократичній регресї в контексті верховенства права.

Ключові слова: Конституція, держава загального добробуту, соціальна держава, права людини, Конституційний Суд.

Постановка проблеми. Соціальна держава стикається з глобальними викликами, такими як: пандемія коронавірусної хвороби (Covid-19), економічний тиск, віковий фактор та старіння населення, «зростаючий оптимізм», зміни на ринку праці та інше. Це призводить до її суттєвих змістових та інституційних змін у XXI столітті, потребуючи їх оновленого осмислення в аспекті механізмів реалізації соціальних прав людини та громадянина.

Аналіз публікацій, у яких започатковано розв'язання задекларованої проблематики. Дослідження питань, що пов'язані із соціальною державою, висвітлено в наукових доробках провідних вітчизняних учених, зокрема: Ю. Г. Барабаша, О. М. Бориславська, С. О. Верланова, М. М. Гультай В. В. Речицького, М. В. Савчин, Ю. М. Тодики, Г.О. Христова, I. В. Яковюка та ін. Вагомий внесок у розробку проблематики в аспекті соціальних прав зробила ціла низка й зарубіжних дослідників, зокрема Г. Ломанн, Г. ЛюббеВельфф, П. Розанваллон, В. Скудра, Д. Стігліц та ін.

Мета статті - визначити загальні історичні передумови розвитку соціальної держави. Дослідити особливості конституційноправової доктрини та юридичних позицій органів конституційної юрисдикції в аспекті гарантування соціальних прав.

Виклад основного матеріалу. У Свропі соціальні послуги, від реєстрації населення до милостині найбіднішим, традиційно надавала церква. Держава поглинула ці функції лише у XX столітті. Так, з кінця XIX століття робітники боролися за свої основні права, а противником їх надання вважалася держава. Але у ті часи масова мобілізація загальні страйки, профспілки та радикальні 
жіночі організації досягали «справжніх перемог» та призводили до надання соціальних гарантій [1, с. 20].

Промислова революція привела до змін у суспільному житті. Більш того, інтелектуальні віяння, викликані епохою Просвітництва і Французької революції, пропагували ідею про бажаність і можливості іншого суспільного ладу, заснованого не на співчутті біднякам, а на понятті «права людини», протиставляючи іï утриманству. Серед робітників, які стали більш організовані і помітні як соціальна сила, популярності набули ідеї соціалізму, які проголошували рівність не тільки можливостей, але й результатів. Це призводило до забезпечення соціального захисту з боку держави. У країнах ліберального толку першими відкликнулися підприємства, що зрештою призвело до появи фірмспонсорів «прихованих держав загального добробуту». У результаті склалися два типи держави загального добробуту: один набув більшого поширення в Свропі, інший в США та інших англосаксонських країнах [2, с. 205].

Успіхи та невдачі держав і ринків відігравали в минулому сторіччі важливу роль у розвитку ідей про їхню місію. Під час світової економічної кризи 1930-х років, коли кожен четвертий робітник не мав роботи, геть усім, крім відданих ідеологів, було важко вважати, ніби ринки завжди ефективні. Тому не дивно, що за тодішніх обставин ідея, що держава повинна відігравати важливішу роль у макроменеджменті, набула сили. До 1960 року в більшості країн на шляху розвитку в усьому світі ринки (принаймні в тій формі, в якій їх сформували колоніальні держави) самі собою не забезпечували зростання економіки.

Джерелом провалів держави є і дуже вичерпні, і надмірно широко сформульовані правила. Тому ми не можемо запропонувати загальну відповідь на питання про те, наскільки деталізовані повинні бути правила, що вводяться державою. Залежно від потреби регулювання практики та від швидкості змін держава повинна встановлювати правила різного ступеня дроблення [3, c. 497].

Тож було природним, що багато людей у тих суспільствах дійшли висновку, що держава має відігравати у розвитку набагато важливішу роль. Проте після краху комунізму всім, крім затятих ідеологів, так само було б важко вважати, ніби держава має відігравати домінантну роль в економіці. 3 цього досвіду, зі спостережень, що ринки часто зазнають невдачі, але так само й держави, природним чином розвинулась ідея, що має бути збалансована роль ринків, держави і громадянського суспільства [4, с. 256]. Це ставало основою для вирішення соціальної проблеми - проблеми нерівності.

Першою, явною причиною скорочення нерівності в післявоєнній Європі $є$ те, що в цей період там розвивалася держава загального добробуту й система соціального забезпечення, які фінансуються - принаймні, частково - за рахунок прогресивного оподаткування доходів. Розширення державного пенсійного забезпечення скоротило масштаби бідності серед літніх людей, а поширення соціальних трансфертів на інші категорії населення (наприклад, на інвалідів) посилило ефективність заходів соціального захисту. Водночас демографічні зміни (зокрема, старіння населення) посилювали потребу у соціальному захисті. У міру збільшення частки матеріально залежного населення все менше рівномірним ставав розподіл ринкових доходів (таких як прибуток, дохід від самозайнятості, рента, дивіденди, відсотки, а також приватні пенсії та інші приватні трансферти). Все більше людей, які залишили ринок праці, показували нульові доходи. По суті, відбувалися «перегони» між збільшенням матеріальних потреб та можливістю [суспільства] їх задовольнити [5, c. 120].

«Звіт Вільяма Беверіджа» заклав підгрунтя розвитку системи державного добробуту у Великій Британії. Його головні рекомендації передбачали значне розширення системи Національного страхування, програми, що забезпечує виплати із безробіття, лікарняних та пенсій, створюючи універсальну мережу безкоштовної медицини під егідою Національної служби охорони здоров’я і вводячи мінімальну платню. Цей звіт мав величезну популярність серед населення Британії. Повоєнний міністр національного страхування, член Лейбористської партії Джеймс Гріффітс, написав у своїх мемуарах: «У найпохмурішу годину повоєнного періоду [цей звіт] був наче манна 3 небес» 6 , с. 395].

Як зазначає Френсіс Фукуяма у своїй відомій праці «Політичний порядок і політичний занепад. Від промислової революції до глобальної демократії», «Медісонова система стримувань і противаг, що так ускладнює ухвалення рішень, дуже затримала прихід американської соціальної «держави загального добробуту», гарантувавши, що та ніколи не виросте до розмірів своїх європейських колег. Чимало американців вважають цю обставину благословенням; вона звільнила економіку США від багатьох згубних правил і стримувальних мотивацій, які 
накладає європейська соціальна політика. Але це також означає, що реформа системи тобто її зменшення й підвищення ефективності її роботи - також буде значно складнішим завданням. Надмірна кількість точок вето, які вкидають пісок у передавальні механізми, ускладнюючи й перешкоджаючи рухові вперед, означає також і складність повернутися назад» [7, с. 326].

Свропейська модель конституціоналізму характеризується тим, що, окрім національних гарантій та інструментів обмеження державного правління на користь прав та свобод людини і громадянина, існують наднаціональні механізми, які досить дієво захищають права та основоположні свободи, а також гарантують соціальні та економічні права, чим ставлять державу у певні юридичні рамки, тим самим реально обмежуючи iii $[8$, c. 18$]$.

Саме права другого покоління (позитивні права, соціальні права) мали значний вплив на порядок денний інституційних реформ, спрямованих на виконання «недосконалих» глобальних обов'язків, які визнавались більш неявно, ніж відкрито. Включення прав другого покоління поєднує етичні проблеми, що лежать в основі загальних ідей глобального розвитку, з вимогами дорадчої демократії, які однаково пов’язані з правами людини і часто 3 розумінням важливості розбудови людського потенціалу [9, с. 483].

Фундаментальний конституційний принцип «соціальної держави» - це установчий елемент європейської конституційної ідентичності на противагу реаліям за межами Західної Європи, особливо американській парадигмі. Фактично всі європейські конституції (за зрозумілим винятком Великобританії) підтверджують цей принцип або явно, шляхом включення положень «про соціальну державу», або неявно, шляхом введення системи конституційного захисту та конституційного переліку соціальних прав.

Окремі країни йдуть шляхом забезпечення через інститут конституційної скарги тільки так званих негативних прав, які мають конституційну силу, тоді як група прав людини, які мають програмний характер (передусім соціальні права, що іноді називаються «соціальні наміри» чи «соціальні цілі»), не наділяється правовими засобами їх захисту. Порушення таких прав (зокрема, їх повне чи часткове незабезпечення) не визнається підставою для подання конституційної скарги.

Так, Верховний Суд Швейцарії користується поняттям «відповідні Конституції права», які базуються на програмних положеннях Конституції про соціально орієнтовану діяльність держави, турботу та допомогу соціальним групам, що потребують підтримки з боку держави, особливо найбільш уразливим верствам населення (особам з обмеженими фізичними можливостями, особам похилого віку, дітям, що залишилися без батьківського піклування тощо). До таких прав належать переважно соціально-економічні права, на які Верховний Суд не поширює судовий захист і право подачі конституційної скарги, у чому і полягає їх відмінність від категорії основних прав.

Орієнтуючись на класичну ліберальну концепцію прав людини, Конституційний Суд Австрійської Республіки також не визнає за соціально-економічними правами громадян статусу основних прав, захист яких забезпечується в судовому порядку. Гарантією таких прав може служити економічна політика уряду, законодавство про державну підтримку безробітних, страхову медицину тощо.

Однак Венеційська Комісія справедливо поставила питання про те, чи має індивідуальна скарга в такому разі обмежуватися тільки тими конституційними правами, які передбачені й у Європейській конвенції. У такому ракурсі запроваджені зміни ведуть до виключення соціальних прав зі сфери дії індивідуальної скарги, тобто звуження обсягу правового захисту, що нею надається. До речі, саме тому визнання Австрією прав, передбачених у Європейській конвенції, як підстави для звернення до Конституційного Суду в разі їх порушення цілком узгоджується з визнаною нею ліберальною концепцією прав людини, що заперечує конституційний захист соціальних прав; соціальні права не завжди є предметом конституційних скарг, оскільки існують побоювання, що вони втратять ефективність і визначення через великий обсяг роботи конституційних судів [10, с. 117].

Відповідно, соціально-економічні права все частіше стають предметом судового (квазісудового) захисту. Про визнання такого підходу на універсальному рівні свідчить запровадження процедури індивідуальної скарги до Комітету ООН із соціальних, економічних та культурних прав. ССПЛ також опосередковано захищає соціально-економічні права тією мірою, якою вони виступають складником реалізації основоположних прав і свобод, гарантованих Конвенцією, наприклад, забезпечення права на чисте довкілля може бути умовою реалізації права на життя. Національна судова практика різних країн світу також доводить здатність соціальноекономічних прав отримувати у відповідних випадках судовий захист. Це свідчить про неподільність усіх прав людини та 
належність їх до «прав» у юридичному сенсі, а не лише до «програмних цілей», навіть за умови визнання певних меж судового захисту соціально-економічних прав [11, с. 48].

Цікаво, що саме віра у ліберальні інституційні рішення у «молодих пострадянських державах» посилюється, при цьому буде мати великий вплив на конституційний дизайн соціальних прав. Тому зростання потенціалу конституцій та/або конституцій консолідації ліберально-демократичної системи в перехідний період $є$ консенсусним явищем для усвідомлення конституційного патріотизму. Практика захисту прав людини все більше рухається у напрямі нормативного та інституційного гарантування, тобто інструменту запобігання демократичної регресії в контексті верховенства права.

Натомість в Україні спостерігається регулярна пролонгація стану підсвідомої недовіри держави до «егоїстичного», за Адамом Смітом, індивіда. Зокрема, вся бюджетно-фінансова, податкова система України побудована на презумпції непорядності приватно господарюючого суб'єкта. Але ж без фундаментально закріплених прав власника й виробника сучасна економічна система працювати не може. I хоча останні є, очевидно, не ангелами, без етики ірраціонального початку в економічній сфері Україна не зможе виборсатися із цивілізаційного болота. Давно вже час збагнути, що чим більше непідробного й суперечливого капіталізму зайде в Україну, тим краще житиметься людям [12, с. 180].

Інституційний складник в Україні характеризується відносинами між органами державної влади. Слід погодитися 3 думкою Ю. Г. Барабаша, що моделі правової, демократичної та соціальної держави мають різні орієнтири, а можливо, що підхід вітчизняного законодавця та урядовців до цих складників державності настільки специфічний, що не дає можливості їх взаємоузгодженого та безконфліктного існування [13, с. 25]. Так, на національному рівні конституційний діалог описує характер взаємодії між трьома гілками влади у сфері прийняття конституційних рішень, особливо тлумачення конституційних прав. У цьому ракурсі знову постає центральне питання про здатність Конституційного Суду України врівноважувати конкуруючі потреби права та політики, наповнювати нормативним змістом рішення, спрямовані на захист соціальних прав.

Як приклад, по відношенню до Верховної Ради Конституційний Суд України може відігравати роль своєрідного як негативного, так і позитивного законодавця. У першому випадку Конституційний Суд може визнати закон або його частину неконституційним, у другому - за допомогою належної юридичної аргументації свого рішення вказати Верховній Раді на необхідність виправити ситуацію, тобто на варіант тлумачення закону, який сумісний 3 конституційними цінностями та принципами, відкинувши інші через неприпустимість їх застосування, оскільки таке буде розцінюватися як порушення Конституції. У випадках констатації факту законодавчого упущення Суд у своєму рішенні зобов'язаний вказувати парламенту на правові форми і засоби його усунення або коригування. Негативним досвідом $є$ рішення КСУ № 3-рп / 2012, яким врозріз з природою прямої дії Конституції України законність трактується як можливість Уряду встановлювати обсяг і зміст соціальних прав шляхом визначення урядовою постановою розміру соціальних виплат. Це стало не чим іншим, як безпосереднім посяганням на сутність права і виправданням довільного втручання виконавчої влади в автономію індивіда, якому відповідно до Конституції має гарантуватися соціальний захист [14, с. 497].

Паліативним виходом із ситуації міг би стати перехід від «реальних» соціальноекономічних прав до прав-орієнтирів за моделлю Міжнародного пакту про економічні, соціальні та культурні права від 16.12 .66 р., прав-гарантій 3 Свропейської соціальної хартії від 03.05 .96 р., правпринципів з Хартії засадничих прав Свросоюзу (додаток до Лісабонського договору від 01.12.09 р.). Такий крок можна було б підсилити конституційним розширенням підприємницької ініціативи індивіда. Однак статистичні показники щодо України свідчать про те, що держава вчиняє щось цілком несумісне зі здоровим економічним інстинктом. Як і раніше, нам бракує юридичних гарантій «розтікання» економічною ентузіазму. Відчуття свободи породжує ініціативу, але українці не мають по-справжньому надійних стимулів і конституційних гарантій підприємницької свободи [12, с. 181].

На жаль, пандемія коронавірусної хвороби (Covid-19) постає небаченим випробуванням, яке загрожує побудованій соціальній солідарності та розширенню захисту прав людини. Початкові реакції держав передбачають безпрецедентну цільову фіскальну та монетарну політику, щоб забезпечити соціальний захист, одночасно стимулюючи економічний пошук задля запобігання зануренню в глобальну депресію. Проте термінові заходи, частіш за все в обхід звичних механізмів участі та прийнятих демократичних стримувань та противаг, можуть призвести до непередбачених обставин. 


\section{Висновки}

В умовах пандемії виникають політичні занепокоєння щодо заходів жорсткої економії, щодо того, що прийняті обмежувальні підходи на основі бюджетних скорочень соціальних витрат, можливо, не досягають своєї мети щодо зміцнення державних бюджетів, але загрожують поглибленням подальшої кризи і завданням шкоди соціальним правам, оскільки вони в основному зачіпають групи з найнижчими доходами та найбільш вразливі категорії населення. Під час кризи уряди не завжди можуть враховувати зв'язок між правами людини і нагальним завданням врятувати економіку від краху. Однак періоди серйозних фінансових труднощів не повинні розглядатися як надзвичайні ситуації, що автоматично призводять до зменшення соціально-економічних прав та погіршення стану вразливих соціальних груп. I навпаки, держави повинні розглядати такі періоди як можливості для перегляду своїх національних систем захисту прав людини та реорганізації своїх власних «бюрократичних адміністрацій» 3 метою побудови або підвищення ефективності національних систем для реального впровадження соціального забезпечення, включаючи мережі соціального захисту, які повинні бути оперативні та своєчасні, де у цьому виникає потреба.

\section{Список використаних джерел:}

1. Срничек Н., Уильямс А. Изобретая будущее: посткапитализм и мир без труда. Москва: Strelka Press, 2019. 336 c.
2. Танци В. Правительство и рынки: Меняющаяся экономическая роль государства. Москва: Изд-во Института Гайдара. 2018. 584 с

3. Долфсма В. Провалы государства. Общество, рынки и правила. Москва: Изд-во Институт Гайдара. 2017. 256 с.

4. Стігліц Д. Ціна нерівності. Київ: Темпора. 2017. $584 \mathrm{c}$.

5. Аткинсон Э.Б. Неравенство: как с ним быть? Москва: Издательский дом «Дело» РАНХиГС. 2018. 536 с

6. Аджемоглу Д., Робінсон Д. Вузький коридор. Держави, суспільства і доля свободи. Київ: Наш формат, 2020.520 c

7. Фукуяма Ф. Політичний порядок і політичний занепад. Від промислової революції до глобальної демократії. Київ : Наш формат, 2019. 608 с.

8. Бориславська О. М. Європейська модель конституціоналізму: системно-аксіологічний аналіз. Харків: Право,2018. 384 с.

9. Сен А. Идея справедливости. Москва: Изд-во Института Гайдара. Фонд «Либеральная Миссия», 2016. 520 с.

10. Гультай М. М. Конституційна скарга у механізмі доступу до конституційного права. Київ : «Центр учбової літератури». 2019. 270 с.

11. Христова Г.О. Позитивні зобов'язання держави у сфері прав людини: сучасні виклики. Харків : Право, 2018. 680 с

12. Речицький В. В. Неформальний конституціоналізм II. Харків: ТОВ «Видавництво «Права людини», 2021. 440 c.

13. Барабаш Ю. Г. Дихотомія правової, демократичної та соціальної державності-тонка грань українського конституціоналізму. Право України. 2010. № 7. C. 24-32.

14. Савчин М.С. Конституционная юстиция в Украине. Конституиионная юстищия в странах Восточной Европы: проблемы теории и практики. Москва: Норма, 2019. 672 с.

Vitalii Kovtun. Constitutional doctrine social rights and freedoms

Participation in the redistribution of budget funds, the creation of social protection networks and economic regulation initiated the principles of public policy. In the middle of the nineteenth century, after the riots of 1848, a decade-long controversy erupted over the most effective way to combat poverty - using government intervention in the economy or relying on laissez-faire policies. The successes and failures of states and markets have played an important role in the development of ideas about their mission in the last century. Awareness of the idea of the "golden mean" was aimed at balancing the role of markets, the state and civil society. The historical process of understanding the phenomenon of the welfare state led to the emergence of the peculiarities of American and European constitutionalization.

The special role of judicial jurisdictions of different legal orders in understanding the idea of the welfare state is emphasized. Constitutional courts should not avoid responsibility for the implementation of social justice in society, and they can achieve this through constitutive interpretation. In particular, examples from the case law of the Constitutional Court of Ukraine on so-called "social cases" are given. The article states that social rights can be ensured by legal norms and sanctions and correspond to a court decision in accordance with the system of constitutional complaints by interpreting them as "classical rights".

It is considered that today the world community is in the deepest recession since World War II. The coronavirus pandemic (Covid-19) is an unprecedented test that threatens to build social solidarity and expand human rights protections. The initial reactions of states include unprecedented targeted fiscal and monetary policies to provide social protection while stimulating economic demand to prevent a fall into the global depression.

The practice of protecting human rights in the "young post-Soviet states" is increasingly moving in the direction of normative and institutional guarantee, ie a tool to prevent democratic regression in the context of the rule of law.

Key words: Constitution, welfare state, social state, humans rights, constitutional court. 